\title{
Assessment of past, present and future health-cost externalities of air pollution in Europe and the contribution from international ship traffic using the EVA model system
}

\author{
J. Brandt ${ }^{1}$, J. D. Silver ${ }^{1}$, J. H. Christensen ${ }^{1}$, M. S. Andersen ${ }^{1}$, J. H. Bønløkke ${ }^{2}$, T. Sigsgaard ${ }^{2}$, C. Geels ${ }^{1}$, A. Gross ${ }^{1}$, \\ A. B. Hansen ${ }^{1}$, K. M. Hansen ${ }^{1}$, G. B. Hedegaard ${ }^{1, *}$, E. Kaas ${ }^{3}$, and L. M. Frohn ${ }^{4}$ \\ ${ }^{1}$ Aarhus University, Department of Environmental Science, Frederiksborgvej 399, 4000 Roskilde, Denmark \\ ${ }^{2}$ Aarhus University, Section of Environmental and Occupational Health, Institute of Public Health, Bartholins Allé 2 , \\ Building 1260, 8000 Aarhus C, Denmark \\ ${ }^{3}$ University of Copenhagen, Planet and Geophysics, Niels Bohr Institute, Juliane Maries Vej 30, 2100 Copenhagen, Denmark \\ ${ }^{4}$ Aarhus University, AU Knowledge, Tuborgvej 164, 2400 Copenhagen , Denmark \\ * now at: Centre for Environmental and Climate Research, Lund university, Sölvegatan 37, 22362 Lund, Sweden
}

Correspondence to: J. Brandt (jbr@dmu.dk)

Received: 7 January 2013 - Published in Atmos. Chem. Phys. Discuss.: 6 March 2013

Revised: 3 July 2013 - Accepted: 10 July 2013 - Published: 12 August 2013

\begin{abstract}
An integrated model system, EVA (Economic Valuation of Air pollution), based on the impact-pathway chain has been developed to assess the health-related economic externalities of air pollution resulting from specific emission sources or sectors. The model system can be used to support policy-making with respect to emission control. In this study, we apply the EVA system to Europe, and perform a more detailed assessment of past, present, and future healthcost externalities of the total air pollution levels in Europe (including both natural and anthropogenic sources), represented by the years 2000, 2007, 2011, and 2020. We also assess the contribution to the health-related external costs from international ship traffic with special attention to the international ship traffic in the Baltic and North seas, since special regulatory actions on sulfur emissions, called SECA (sulfur emission control area), have been introduced in these areas. We conclude that, despite efficient regulatory actions in Europe in recent decades, air pollution still constitutes a serious problem for human health. Hence the related external costs are considerable. The total health-related external costs for the whole of Europe are estimated at $803 \mathrm{bn}$ euros $\mathrm{yr}^{-1}$ for the year 2000 , decreasing to $537 \mathrm{bn}$ euros $\mathrm{yr}^{-1}$ in the year 2020. We estimate the total number of premature deaths in Europe in the year 2000 due to air pollution to be around $680000 \mathrm{yr}^{-1}$, decreasing to approximately $450000 \mathrm{in}$
\end{abstract}

the year 2020. The contribution from international ship traffic in the Northern Hemisphere was estimated to $7 \%$ of the total health-related external costs in Europe in the year 2000, increasing to $12 \%$ in the year 2020. In contrast, the contribution from international ship traffic in the Baltic Sea and the North Sea decreases $36 \%$ due to the regulatory efforts of reducing sulfur emissions from ship traffic in SECA. Introducing this regulatory instrument for all international ship traffic in the Northern Hemisphere, or at least in areas close to Europe, would have a significant positive impact on human health in Europe.

\section{Introduction}

Air pollution has significant negative impacts on human health and well-being, entailing substantial economic consequences. In order to carry out regulatory actions, knowledge about the magnitude of the problem, both with respect to number of cases of the different health impacts (morbidity and mortality) as well as estimates of the total external costs related to these impacts, is required. An assessment of the health-related external costs from air pollution, based on the best available methodologies, is a powerful tool for decision-making, since the external costs can be compared 
to other socio-economic costs and can be used for ranking of environmental stressors by health impact (see, for example, Hänninen et al., 2011).

Amann et al. (2005) and Watkiss et al. (2005) provide recent examples of this in the European context; these authors modelled the effects of implementing the EU's directives on atmospheric ozone and PM concentrations. They estimated that the annual costs of ozone and PM in the EU-25 countries amounted to between 276 bn euros $\mathrm{yr}^{-1}$ and $790 \mathrm{bn}$ euros $\mathrm{yr}^{-1}$ in the year 2000, and that this is expected to decrease by $87 \mathrm{bn}$ euros $\mathrm{yr}^{-1}$ and 181 bn euros $\mathrm{yr}^{-1}$ in 2020 , if the directives are followed. A similar assessment of reducing emissions by $30 \%$ in Europe is found in Jensen and Leetz (2010).

We have developed an integrated model system, EVA (Economic Valuation of Air pollution; Brandt et al., 2013), to assess health-related economic externalities of air pollution. The EVA system integrates a regional-scale atmospheric chemistry transport model, DEHM (the Danish Eulerian Hemispheric Model; Brandt et al., 2012), gridded population data, exposure-response functions, and monetary valuation applicable for European conditions. The EVA system has the advantage compared to other similar systems that it estimates the actual contribution from specific emission sources and how they influence air pollution levels without assuming linearity of the non-linear behaviour of atmospheric chemistry. For this purpose a tagging method has been implemented, calculating source-receptor relationships where the emission scenario of interest is calculated simultaneously together with the background chemistry in the DEHM model. A thorough description and documentation of the EVA system is given in Brandt et al. (2013). The DEHM model, as well as the full integrated EVA system, is part of the integrated THOR air pollution and management system (Brandt et al., 2001a, b, c, 2003, 2007).

The focus of the paper is three-fold: firstly, to estimate the contribution of the international ship traffic to health-related external costs; secondly, to estimate the total health impacts and related external costs from the total air pollution (which is also needed to calculate the contribution from the international ship traffic); and, thirdly, to calculate the changes over time to investigate whether the present measures are sufficient. Using the EVA system, we assessed the total impacts on human health and related external costs due to total air pollution levels in Europe (defined by model domain 2 in the DEHM model, which includes the whole of Europe; see Fig. 2), and compared the results to other similar studies. Furthermore, we estimated the impacts and external costs of air pollution stemming from emissions from international ship traffic, since this sector is an important contributor. As part of this, we examined the impacts of introducing the socalled SECA (sulfur emission control area) in the North Sea and Baltic Sea. Both for international ship traffic and for the total air pollution levels, results are presented for past, present, and future conditions, represented by the emission years 2000, 2007, 2011, and 2020. For the first three years, emissions are based on the EMEP emission database. For the year 2020, emissions are based on the NEC-II emissions for Europe in order to assess the impacts of the future general emission reductions.

More specifically, the aim in this study can be divided into answering three questions. (1) What are the past, present, and future impacts on human health and related external costs in Europe from all international ship traffic in the Northern Hemisphere? (2) What are the past, present, and future impacts on human health and related external costs in Europe from international ship traffic in the Baltic Sea and the North Sea? (3) What are the total health impacts and associated externalities from the past, present, and future total air pollution levels from all anthropogenic and natural sources?

There are two reasons for estimating the total impacts from past, present, and future air pollution levels: first, in the public debate as well as in political decision-making processes, it is useful to have estimates of the total impacts from air pollution in order to quantify the magnitude of the problem. These calculations can be used as a basis for socio-economic research and discussions on the costs and benefits of carrying out emission-reduction strategies. Second, the results can be compared to other similar studies where the total impacts from air pollution have been estimated. The most important comparison in this case is with the results from the CAFE (Clean Air for Europe) project (Watkiss et al., 2005; Amann et al., 2005). These comparisons constitute the closest we can come to an evaluation of the integrated EVA model system. If the results are similar for the total air pollution levels, we can have greater confidence in the results from the scenarios, yet we emphasize that the two results being compared are both subject to significant uncertainties and different assumptions.

In Sect. 2, a short description of the EVA model system is given. In Sect. 3, the simulations set up to answer the questions defined above are described and the results from the individual scenarios using the EVA model system are presented. Section 4 includes the general results and these are discussed and compared with similar results from CAFE (Clean Air For Europe). Finally, Sect. 5 contains the overall conclusions of this work.

\section{The integrated EVA model system}

The concept of the EVA system (Frohn et al., 2006, 2007; Andersen et al., 2006, 2007, 2008; Brandt et al., 2010, 2013) is based on the impact-pathway chain (e.g. Friedrich and Bickel, 2001) and also used in the EcoSense model (ExternE, 1997, 1998, 1999, 2005). The EVA system consists of a regional-scale chemistry transport model (CTM), the DEHM model (Christensen, 1997; Christensen et al., 2004; Frohn et al., 2001, 2002; Brandt et al., 2012), address-level or gridded population data, exposure-response functions for health impacts, and economic valuations of the impacts from 
air pollution. A detailed description of the integrated EVA model system is given in Brandt et al. (2013).

The essential idea behind the EVA system is that the best available and most accurate yet computationally demanding methods are used in each part of the impact-pathway chain. The EVA system uses a comprehensive and thoroughly tested chemical transport model when calculating how specific changes to emissions affect air pollution levels. The geographic domain used in DEHM covers the Northern Hemisphere and, therefore, describes the intercontinental atmospheric transport, including higher resolution two-way nesting over Europe and even higher resolution over northern Europe (see Figs. 1, 2, and 3). All scenarios are simulated individually and not estimated using linear interpolation or extrapolation from standard reductions, as used in the RAINS/GAINS system (Alcamo et al., 1990; Klaassen et al., 2004).

To estimate the effect of a specific emission source or emission sector, emission inventories for the specific sources are implemented in DEHM, together with all other relevant anthropogenic and natural emission sources. However, quantifying the contribution from specific emission sources to the atmospheric concentration levels is a challenge, especially if the emissions of interest are relatively small. Numerical noise in atmospheric models can be of a similar order of magnitude as the signal from the emissions of interest. To calculate the $\delta$-concentrations (i.e. the marginal difference in regional ambient concentration levels due to a specific emission source), we have implemented a "tagging" method (Brandt et al., 2012, 2013) to examine how specific emission sources influence air pollution levels, without assuming linear behaviour of atmospheric chemistry, and at the same time reducing the influence from the numerical noise. This method is more precise than taking the difference between two concentration fields. Tagging methods have been used elsewhere with chemical transport models (e.g. see Pfister et al., 2008; Sudo and Akimoto, 2007), and are often used for specific species. Here, however, we use tagging to track the effects of the specific source for the full chemical scheme.

Estimates of $\delta$-concentrations are combined with addresslevel population data for Denmark and gridded population data for the rest of Europe to calculate the exposure. Population-level health outcomes are estimated by combining population-level exposure with exposure-response functions found in the literature. External costs for the entire population are estimated using cost functions customized for European conditions in the EVA model system (Brandt et al., 2013).

\section{Definition of scenarios and detailed results}

In this section, a number of model simulations are defined in order to answer specific questions (Sect. 3.1). In Sect. 3.2, the results from the individual scenario runs are discussed.
The overall results will be presented and discussed at an aggregated level in Sect. 4.

\subsection{Definition of overall questions and scenarios}

All results are given as human health impacts and external costs for the whole of Europe, covered by the second domain in the DEHM model (see Fig. 2). In the northern part of Europe, higher resolution results are obtained and substitute the lower resolution results in this area. When making decisions about regulation of specific emission sectors, it is important to consider all impacts from the emission sources of interest from all affected countries. Therefore, we take into account the impacts in the whole European model domain.

To answer the overall questions given in the Introduction, a number of different model simulations have been defined in order to estimate health-related externalities from different kinds of emission sources (see Table 1). Each scenario is defined by three attributes. (1) The region is where the emission sources are located. In this work, the regions are the full northern hemispheric model domain (all), or the Baltic Sea together with the North Sea (BaS-NoS). (2) The emission sectors are defined using the Selected Nomenclature for Air Pollution (SNAP) categories. In this case we have chosen all anthropogenic and natural emissions in the Northern Hemisphere (all) or SNAP category 15 , which we have defined as international ship traffic in our model system (this is usually contained in SNAP category 8 - "other mobile sources"). (3) The emission year (either $2000,2007,2011$ or 2020) was chosen because it is relevant for regulatory emission reduction actions. In all years maximum sulfur content has been defined for the heavy bunker fuel used by the international ships in the SECA. For the year 2020, the emission scenario in the present work consists of a specific set of assumptions. It is expected that a new international directive on national emission ceilings to be reached in 2020 (NEC-II) will be proposed in the near future. In this study the applied scenario for land-based emissions is a combination of the EU Thematic Strategy on Air Pollution and scenarios for the 27 EU countries prepared by the International Institute for Applied Systems Analysis (Amann et al., 2005) as part of the preparatory work of the upcoming NEC-II directive.

The scenarios All/15 (see Table 1 for the definition) for the years 2000, 2007, 2011, and 2020 are defined in order to answer question 1 defined in the Introduction: what are the past, present and future impacts on human health and related external costs in Europe from all international ship traffic in the Northern Hemisphere? In these simulations, the EMEP emissions covering Europe have been used for the model calculations. The 2011 emissions are based on the 2007 emissions but with changes according to the agreements within the sulfur emission control areas (SECAs) for international ship traffic. For the year 2020, the total emissions for each country are based on the National Emission Ceilings directive, version 2 (NEC-II) but using the 2007 spatial emission 

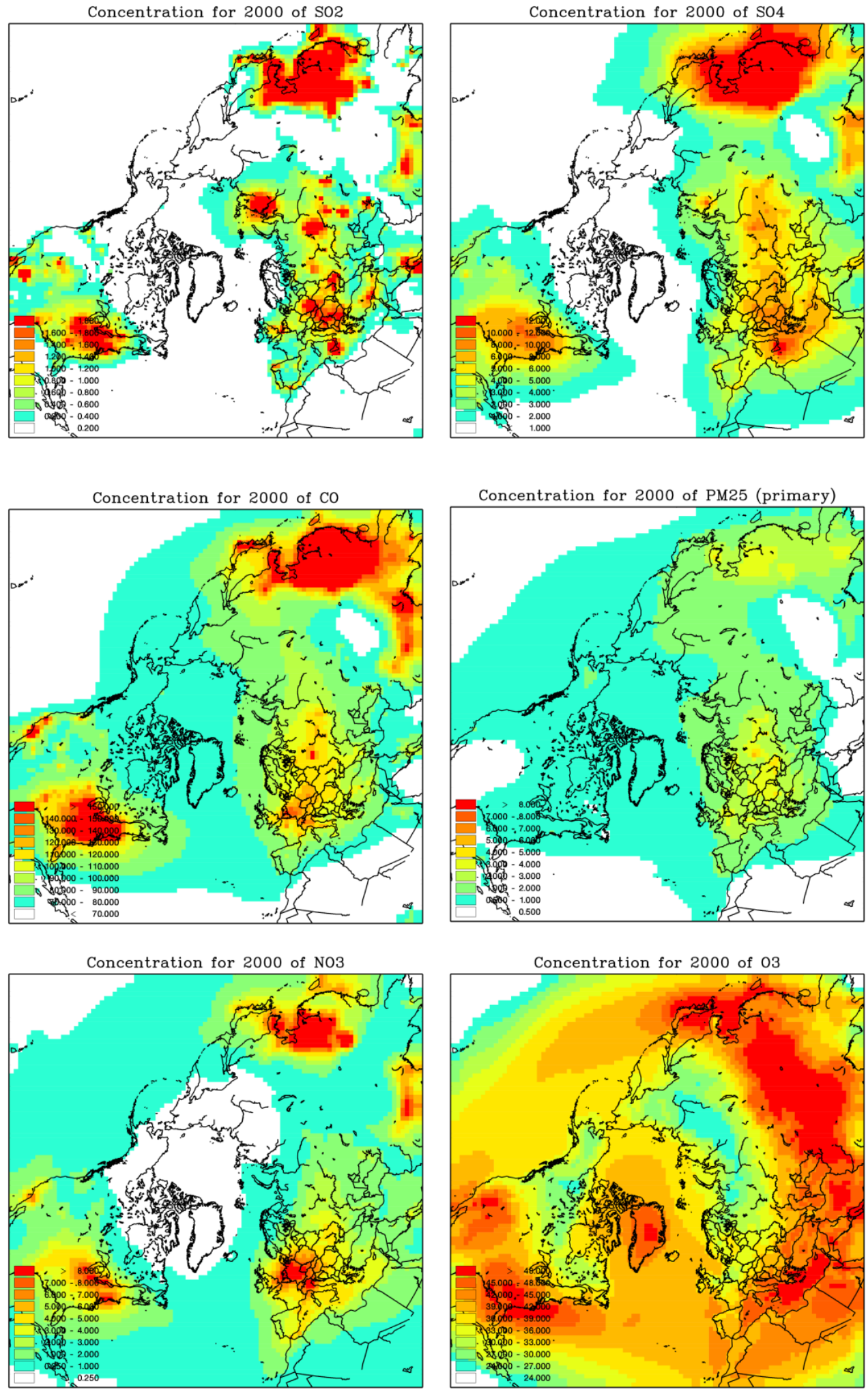

Fig. 1. Mean annual air pollution levels calculated using the DEHM model due to emission from the Northern Hemisphere for the year 2000. The compounds are $\mathrm{SO}_{2}[\mathrm{ppb}], \mathrm{SO}_{4}^{2-}\left[\mu \mathrm{g} \mathrm{m}^{-3}\right], \mathrm{CO}$ [ppm], $\mathrm{PM}_{2.5}$ (primary part) $\left[\mu \mathrm{g} \mathrm{m}^{-3}\right], \mathrm{NO}_{3}^{-}\left[\mu \mathrm{g} \mathrm{m}^{-3}\right.$ ] and $\mathrm{O}_{3}$ [ppb]. Results are shown for the DEHM northern hemispheric domain. 

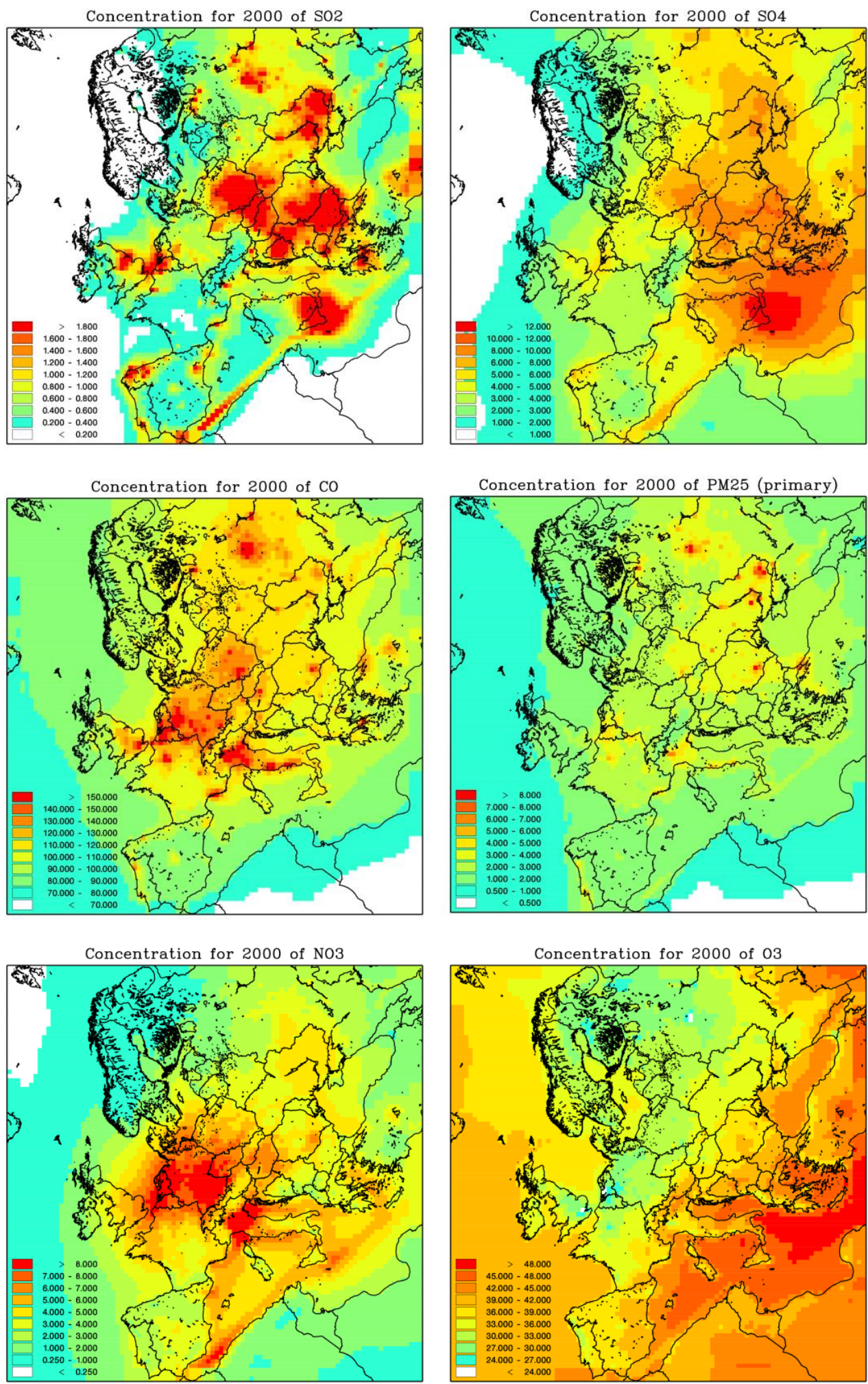

Fig. 2. As Fig. 1, but for DEHM European model domain. 

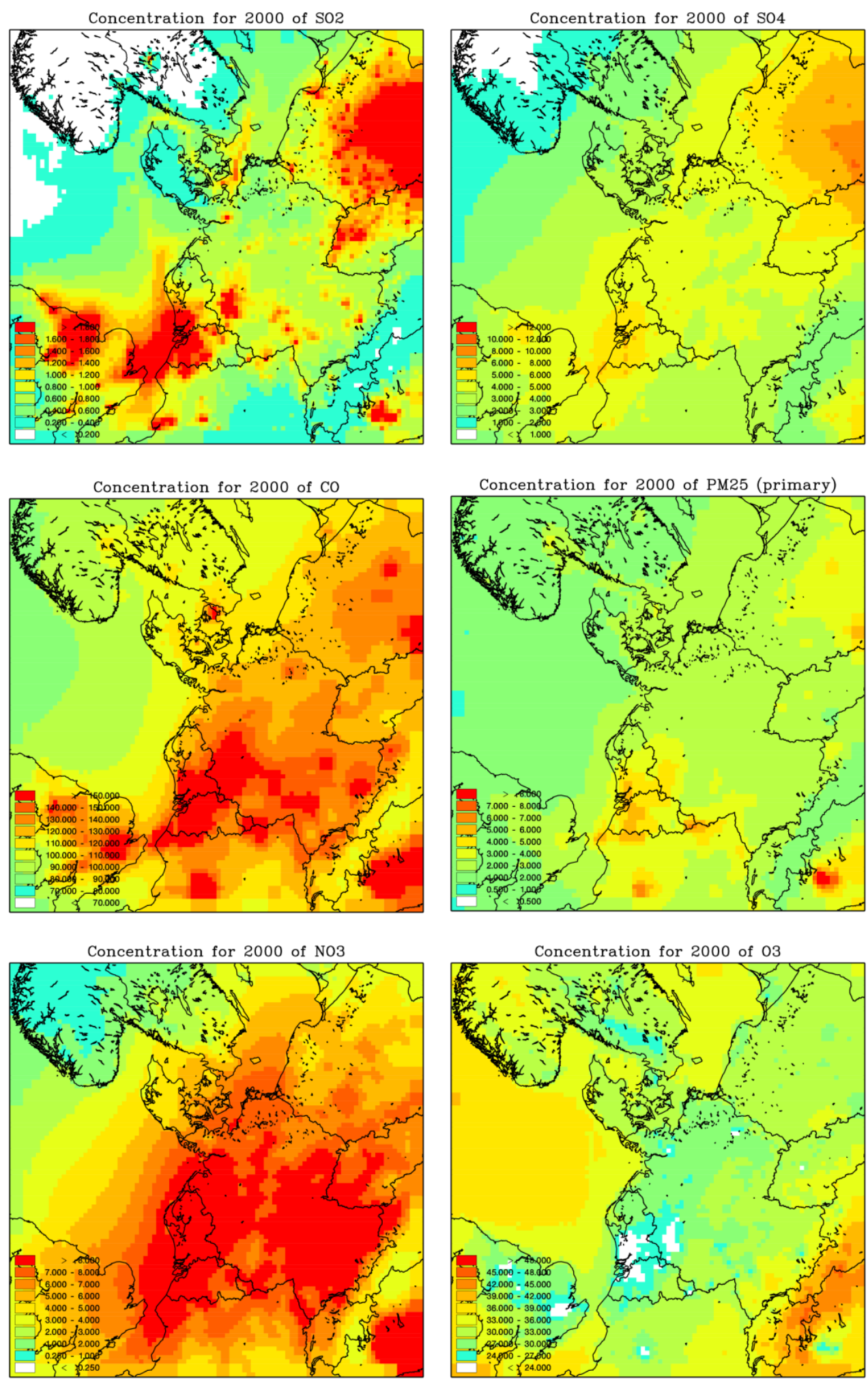

Fig. 3. As Fig. 1, but for DEHM northern European model domain. 
Table 1. Definition of the specific scenarios (or "tags" in the model). Each scenario is defined by a region and a SNAP category (first column), an emission year (second column), and a short description of the emissions of interest in the scenario (column 3).

\begin{tabular}{|c|c|c|}
\hline $\begin{array}{l}\text { Region/ } \\
\text { SNAP }\end{array}$ & $\begin{array}{l}\text { Emission } \\
\text { year }\end{array}$ & Emission scenario (or the "tag") \\
\hline All/15 & 2000 & Int. ship traffic for the year $2000(S=2.7 \%)^{*}$ whole model domain $(E M E P=2000)$ \\
\hline All/15 & 2007 & Int. ship traffic for the year 2007, NoS/BaS: $\mathrm{S}=1.5 \% *$, whole domain $(\mathrm{EMEP}=2006)$ \\
\hline All/15 & 2011 & Int. ship traffic for the year 2011, NoS/BaS: $\mathrm{S}=1.0 \% *$, whole domain $(\mathrm{EMEP}=2006)$ \\
\hline All/15 & 2020 & Int. ship traffic for the year $2020, \mathrm{NoS} / \mathrm{BaS}: \mathrm{S}=0.1 \% *$, whole model domain (NEC-II) \\
\hline BaS-NoS/15 & 2000 & Int. ship traffic for the year $2000(\mathrm{~S}=2.7 \%)^{*}$ whole model domain $(\mathrm{EMEP}=2000)$ \\
\hline BaS-NoS/15 & 2007 & Int. ship traffic for the year 2007, NoS/BaS: $\mathrm{S}=1.5 \% *$, whole domain $(\mathrm{EMEP}=2006)$ \\
\hline BaS-NoS/15 & 2011 & Int. ship traffic for the year 2011, NoS/BaS: $S=1.0 \% *$, whole domain $(\mathrm{EMEP}=2006)$ \\
\hline BaS-NoS/15 & 2020 & Int. ship traffic for the year $2020, \mathrm{NoS} / \mathrm{BaS}: \mathrm{S}=0.1 \%{ }^{*}$, whole model domain (NEC-II) \\
\hline All/all & 2000 & $\begin{array}{l}\text { All emissions (anthropogenic; GEIA/EDGAR; EMEP } 2000 \text { + natural; international ship traffic as } \\
\text { All/15 for the year 2000) }\end{array}$ \\
\hline All/all & 2007 & $\begin{array}{l}\text { All emissions (anthropogenic; GEIA/EDGAR; EMEP } 2006 \text { + natural; international ship traffic as } \\
\text { All/15 for the year 2007) }\end{array}$ \\
\hline All/all & 2011 & $\begin{array}{l}\text { All emissions (anthropogenic: GEIA/EDGAR, EMEP } 2006 \text { + natural; international ship traffic as } \\
\text { All/15 for the year 2011) }\end{array}$ \\
\hline All/all & 2020 & $\begin{array}{l}\text { All emissions (anthropogenic: GEIA/EDGAR; NEC-II + natural; international ship traffic as } \\
\text { All/15 for the year 2020) }\end{array}$ \\
\hline
\end{tabular}

* The North Sea (NoS) and Baltic Sea (BaS) are part of the sulfur emission control areas (SECAs).

distribution, since the NEC-II emissions are given as country totals. In the four years $(2000,2007,2011$, and 2020), different ceilings for the sulfur content of the heavy bunker fuel used by the ships are introduced in the SECA. For the year 2000 , a maximum of $2.7 \%$ of sulfur in the fuel is allowed, decreasing to $1.5 \%$ in $2007,1 \%$ in 2011 and $0.1 \%$ in the year 2015; the latter is used for the 2020 scenario in this study.

The scenarios BaS-NoS/15 are defined to answer question 2: what are the past, present and future impacts on human health and related external costs in Europe from international ship traffic in the Baltic Sea and the North Sea? The scenarios are similar to the scenarios defined above, except in this case we examine only emissions from international ship traffic in the Baltic Sea and the North Sea.

The All/all scenarios are defined to answer question 3: what are the total health impacts and associated externalities from the past, present and future total air pollution levels from all anthropogenic and natural sources? In this case we aim to estimate the total impact on human health and related externalities from all air pollution, regardless of its origin. To do this, the total air pollution levels due to all emissions (both anthropogenic and natural) for the four different years are used as input to the human health impacts module as well as the external cost module in the EVA model system.

\subsection{Examples of DEHM model results from the individual scenarios}

In this section, we present some examples of DEHM model results from the individual scenarios defined in the previous section. The figures shown include plots of annual mean air pollution concentrations over the three geographical domains (Northern Hemisphere, Europe, and northern Europe) either as total air pollution levels or as $\delta$-functions from the individual model runs for the six chemical compounds related to health impacts in the system $\left(\mathrm{SO}_{2}, \mathrm{SO}_{4}^{2-}, \mathrm{CO}\right.$, primary $\mathrm{PM}_{2.5}$ (including $\mathrm{BC}, \mathrm{OC}$ and mineral dust), $\mathrm{NO}_{3}^{-}$, and $\mathrm{O}_{3}$ ). Meteorological data for all scenarios are based on the year 2000 and calculated using the MM5v3 meteorological model defined on the same nested grids as the DEHM model (Brandt et al., 2012).

Figures 1-3 show the mean annual air pollution levels due to the emissions from the whole Northern Hemisphere for the year 2000. Results are shown for the model domains covering the Northern Hemisphere (domain 1), Europe (domain 2), and northern Europe (domain 3). Figures 1-3 correspond to the scenarios All/all (total air pollution levels from all sources) for the year 2000 in Table 1.

Figure 4 shows the mean annual air pollution levels for the year 2020 (European domain). The corresponding result for the year 2000 is shown in Fig. 2. Figure 4 corresponds to the scenarios All/all for the year 2020 in Table 1.

Figures 5 and 6 show the contribution to the annual mean air pollution levels ( $\delta$-concentrations) due to the emissions from the Northern Hemisphere for SNAP category 15 (defined here as international ship traffic) for the years 2000 and 2020 , respectively. The figures correspond to the scenarios All/15 in Table 1. While the land-based emissions in general are decreasing, the emissions from the international ship traffic are generally increasing (except in the North Sea and Baltic Sea), and therefore it is expected that the relative impacts from ship traffic will increase in the future. 

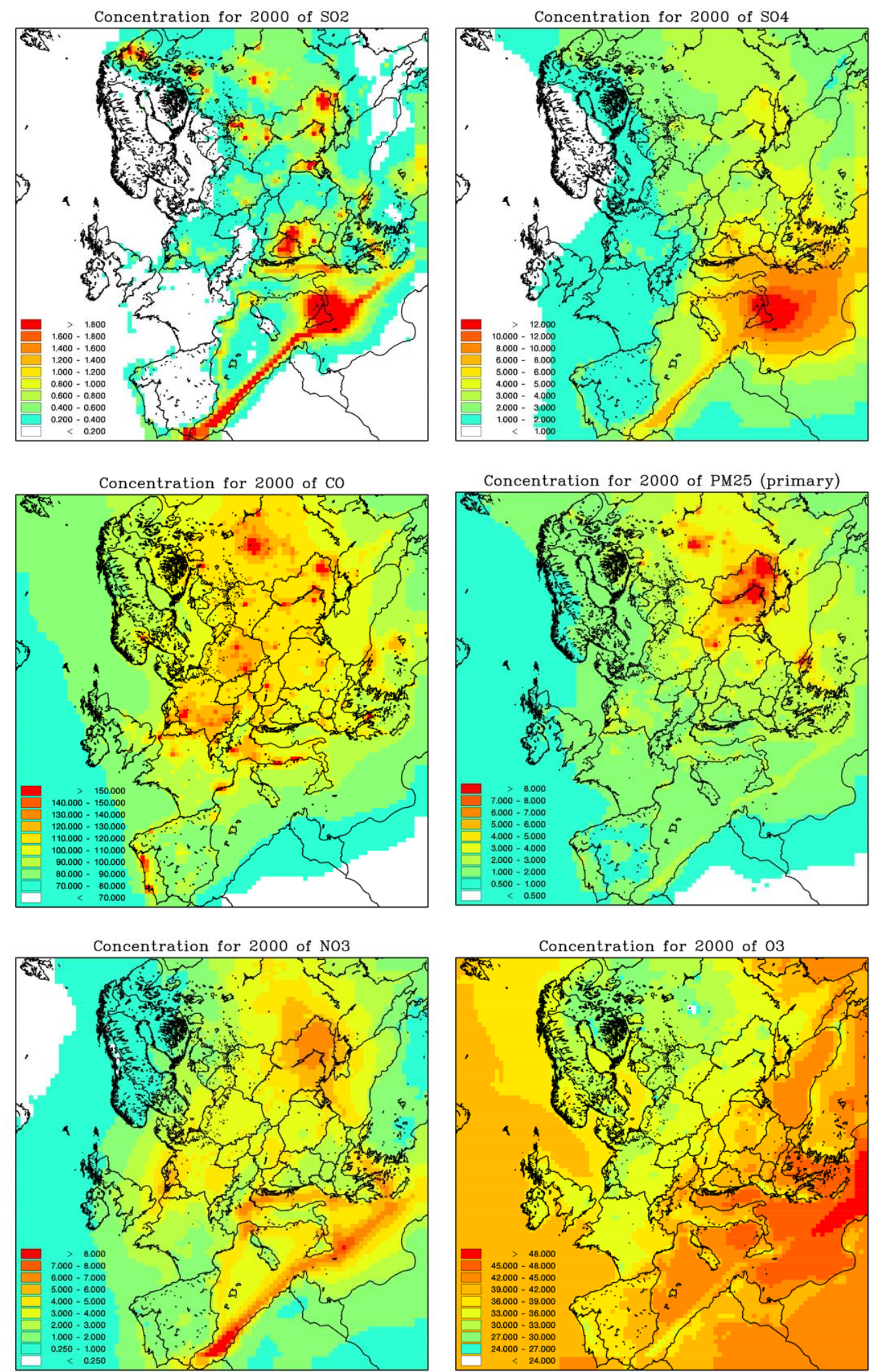

Fig. 4. As Fig. 2, but for the year 2020. 

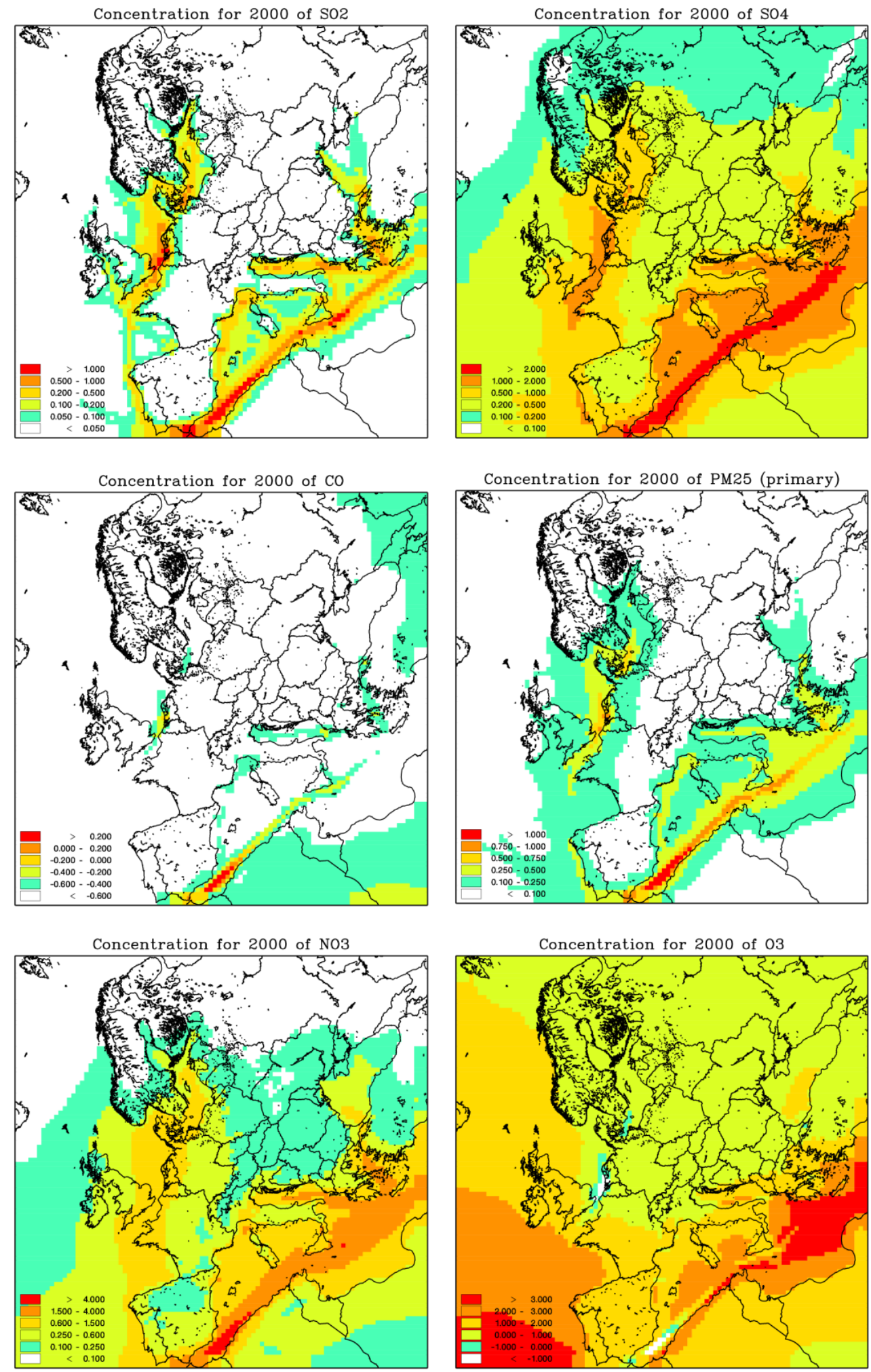

Fig. 5. Contribution to the mean annual air pollution levels ( $\delta$-concentrations) calculated using the DEHM model due to emissions from the Northern Hemisphere from international ship traffic for the year 2000. The compounds are $\mathrm{SO}_{2}[\mathrm{ppb}], \mathrm{SO}_{4}^{2-}\left[\mu \mathrm{g} \mathrm{m}^{-3}\right.$ ], CO [ppm], $\mathrm{PM}_{2.5}$ (primary part) $\left[\mu \mathrm{g} \mathrm{m}^{-3}\right], \mathrm{NO}_{3}^{-}\left[\mu \mathrm{g} \mathrm{m}^{-3}\right]$ and $\mathrm{O}_{3}[\mathrm{ppb}]$. Results are shown for DEHM domain number 2. 

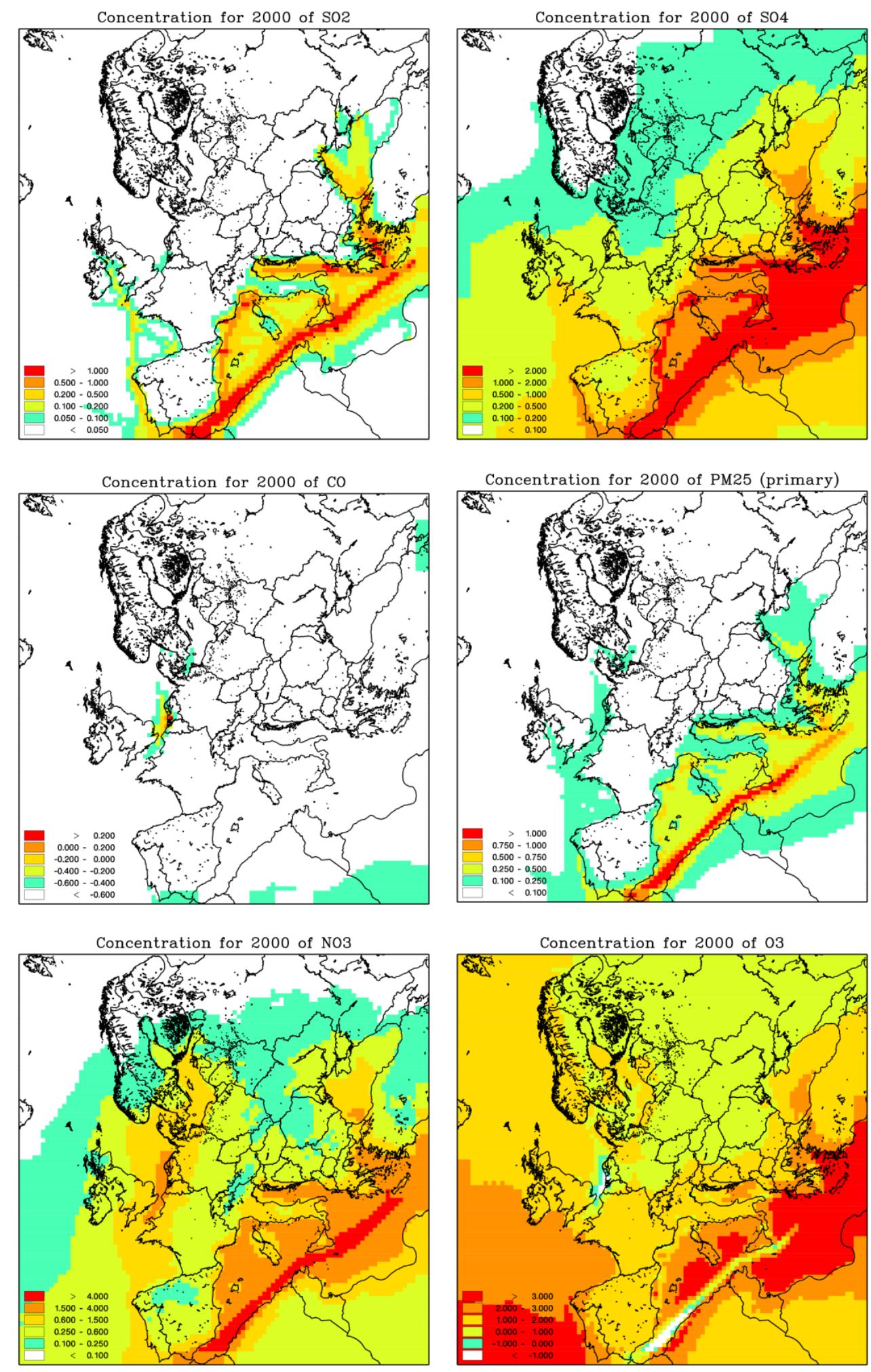

Fig. 6. As Fig. 5, but for the year 2020. 
Table 2. Total number of cases in Europe of the different impacts related to international ship traffic in the Northern Hemisphere (scenario: All/15) for the four different years.

\begin{tabular}{lcccc}
\hline Health impact & \multicolumn{3}{c}{ Number of cases in Europe } \\
Year & 2000 & 2007 & 2011 & 2020 \\
\hline Chronic bronchitis & 46000 & 44900 & 42800 & 49600 \\
Restricted activity days & 47000000 & 45900000 & 43700000 & 50700000 \\
Respiratory hospital admissions & 2670 & 2550 & 2410 & 2770 \\
Cerebrovascular hospital admissions & 5900 & 5760 & 5490 & 6360 \\
Congestive heart failure & 2990 & 2920 & 2780 & 3220 \\
Lung cancer & 7050 & 6880 & 6550 & 7590 \\
Bronchodilator use, children & 1370000 & 1340000 & 1280000 & 1480000 \\
Bronchodilator use, adults & 9010000 & 8790000 & 8370000 & 9710000 \\
Cough, children & 4750000 & 4630000 & 4410000 & 5120000 \\
Cough, adults & 9270000 & 9050000 & 8620000 & 9990000 \\
Lower respiratory symptoms, children & 1830000 & 1790000 & 1700000 & 1970000 \\
Lower respiratory symptoms, adults & 3340000 & 3260000 & 3110000 & 3600000 \\
Acute mortality & 3630 & 3500 & 3400 & 4470 \\
Chronic mortality (YOLL) & 525000 & 512000 & 488000 & 566000 \\
Infant mortality & 52 & 50 & 48 & 56 \\
\hline
\end{tabular}

Table 3. Total number of cases in Europe of the different impacts related to international ship traffic in the Baltic Sea and the North Sea (scenario: BaS-NoS/15) for the four different years.

\begin{tabular}{lcccc}
\hline Health impact & \multicolumn{4}{c}{ Number of cases in Europe } \\
\cline { 2 - 5 } Year & 2000 & 2007 & 2011 & 2020 \\
\hline Chronic bronchitis & 18900 & 15100 & 13100 & 12300 \\
Restricted activity days & 19400000 & 15500000 & 13400000 & 12600000 \\
Respiratory hospital admissions & 1160 & 882 & 746 & 660 \\
Cerebrovascular hospital admissions & 2430 & 1940 & 1680 & 1580 \\
Congestive heart failure & 1250 & 1000 & 867 & 814 \\
Lung cancer & 2900 & 2320 & 2000 & 1880 \\
Bronchodilator use, children & 565000 & 451000 & 390000 & 367000 \\
Bronchodilator use, adults & 3710000 & 2960000 & 2560000 & 2410000 \\
Cough, children & 1950000 & 1560000 & 1350000 & 1270000 \\
Cough, adults & 3820000 & 3050000 & 2640000 & 2480000 \\
Lower respiratory symptoms, children & 753000 & 601000 & 520000 & 489000 \\
Lower respiratory symptoms, adults & 1380000 & 1100000 & 951000 & 894000 \\
Acute mortality & 555 & 240 & 143 & 251 \\
Chronic mortality (YOLL) & 216000 & 172000 & 149000 & 140000 \\
Infant mortality & 21 & 17 & 15 & 14 \\
\hline
\end{tabular}

\section{Overall results and discussions}

The main objective of this work is to make a general assessment of the health-related externalities of air pollution at the European level. This section describes this assessment, first related to the health impacts in Sect. 4.1 and to the total health-related externalities in Sect. 4.2. In Sect. 4.3 a comparison with results from Clean Air for Europe is given.

\subsection{Health impacts}

The overall EVA model results for human health impacts are presented in the tables in this section. The tables summarize the results that are related to the three overall questions defined in the Introduction.

Table 2 presents the number of cases of different health impacts in Europe, related to international ship traffic in the Northern Hemisphere (scenario: All/15) for the four different years. The results in this table relate to question 1. Table 3 gives the number of cases in Europe related to international ship traffic in the Baltic Sea and the North Sea (scenario: $\mathrm{BaS}-\mathrm{NoS} / 15$ ) for the four different years. The results in this table relate to question 2. Finally, Table 4 shows the number of cases in Europe due to the total air pollution concentrations (scenario: All/all) for the four different years. The 
Table 4. Total number of cases in Europe of the different impacts related to all the emissions in the Northern Hemisphere - i.e. the total air pollution levels (scenario: All/all) for the four different years.

\begin{tabular}{lcccc}
\hline \multirow{2}{*}{ Health impact } & \multicolumn{4}{c}{ Number of cases in Europe } \\
\cline { 2 - 5 } Year & 2000 & 2007 & 2011 & 2020 \\
\hline Chronic bronchitis & 633000 & 535000 & 532000 & 418000 \\
Restricted activity days & 647000000 & 547000000 & 544000000 & 427000000 \\
Respiratory hospital admissions & 37800 & 31400 & 31200 & 23800 \\
Cerebrovascular hospital admissions & 81200 & 68600 & 68200 & 53600 \\
Congestive heart failure & 50200 & 42700 & 42500 & 35200 \\
Lung cancer & 96900 & 81900 & 81400 & 64000 \\
Bronchodilator use, children & 18900000 & 16000000 & 15900000 & 12500000 \\
Bronchodilator use, adults & 124000000 & 105000000 & 104000000 & 81800000 \\
Cough, children & 65300000 & 55200000 & 54900000 & 43100000 \\
Cough, adults & 128000000 & 108000000 & 107000000 & 84200000 \\
Lower respiratory symptoms, children & 25200000 & 21300000 & 21200000 & 16600000 \\
Lower respiratory symptoms, adults & 46000000 & 38800000 & 38600000 & 30400000 \\
Acute mortality & 49800 & 43900 & 43700 & 36200 \\
Chronic mortality (YOLL) & 7220000 & 6100000 & 6070000 & 4770000 \\
Infant mortality & 710 & 599 & 596 & 468 \\
\hline
\end{tabular}

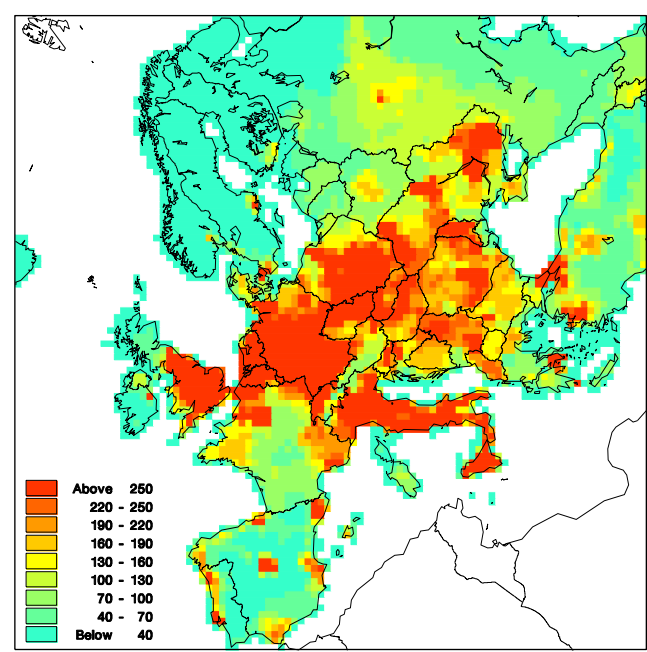

Fig. 7. Number of premature deaths per grid cell in Europe (DEHM European model domain) as calculated with the integrated EVA model system for the year 2000 for the total air pollution levels (scenario All/all). The area of the grid cells is $50 \mathrm{~km} \times 50 \mathrm{~km}=2500 \mathrm{~km}^{2}$, so the colours refer to the number of premature deaths per $2500 \mathrm{~km}^{2}$. The total number of premature deaths in the whole model domain is 680000 , calculated from the number of YOLL (see Table 6) divided by a factor of 10.6 (as used in the CAFE; Watkiss et al., 2005). High numbers of premature deaths (as shown in the figure) require both high levels of annual particle concentrations and high population density. In the year 2020, the number of premature deaths in Europe is estimated to decrease to 450000 .

results in this table relate to question 3: what are the total impacts from the past, present, and future air pollution levels? As an example of these results, Fig. 7 shows the geographical distribution of premature deaths in Europe calculated from the chronic mortality (in years of life lost, YOLL) for the year 2000 divided by a factor of 10.6 as given in Watkiss et al. (2005). The difference in proportionality between the different impacts is due to differences in the proportionality for the different pollutants causing the different impacts (see Table 1 in Brandt et al., 2013)

The results in Tables 2-4 show that the impacts on human health due to air pollution from the different sectors are predicted to decrease during the period 2000-2020, with the exception of the impacts due to international ship traffic, where an increase is expected for the year 2020. This is due to a general increase in international ship traffic according to the projected ship emissions provided by Corbett and Fischbeck (1997). The increase in acute mortality in 2020 for the Baltic Sea is due to an increase in ozone concentrations in the Baltic countries due to an increase in the $\mathrm{NO}_{\mathrm{x}}$ emissions from the international ship traffic in 2020 in the Baltic Sea according to the emission inventories. At the same time, the contribution to particle concentration is decreased due to the SECA restrictions.

\subsection{The total health-related cost externalities}

In this section, the external costs are given for the different scenarios and we present our answers to the questions defined in the Introduction.

Section 4.1 included a summary of the human health impacts. Table 5 shows the total external costs in euros for the whole of Europe related to these health impacts, broken down by chemical compound for all the different scenarios. Exposure-response functions are included for both $\mathrm{SO}_{2}$ and $\mathrm{SO}_{4}^{2-}$. Sulfur emissions are mainly (95\%) emitted 
as $\mathrm{SO}_{2}$, which in the atmosphere is chemically transformed into $\mathrm{SO}_{4}^{2-}$. Therefore, the total external costs related to the emission of $\mathrm{SO}_{2}$ include the human health impacts from both $\mathrm{SO}_{2}$ and $\mathrm{SO}_{4}^{2-}$ (cf. "Total S" in Table 5). Similarly, the external costs related to $\mathrm{O}_{3}$ and $\mathrm{NO}_{3}^{-}$are summed into "Total N". Emissions of $\mathrm{NO}_{\mathrm{x}}$ can lead to both a decrease and an increase of $\mathrm{O}_{3}$ in different areas, and both the costs and the benefits are included in the external costs for $\mathrm{O}_{3}$. The primary emitted part of $\mathrm{PM}_{2.5}$ consists of mineral dust, black carbon, and organic carbon; these are treated as inert tracers in the DEHM model, and can therefore be considered as a direct effect due to emissions of the same chemical compound.

In Table 6, the total health-related externalities for Europe are shown for all scenarios. These include the international ship traffic in the Northern Hemisphere (All/15), the international ship traffic in the Baltic Sea and the North Sea (BaSNoS/15), and all emissions in the whole of Europe (All/all). All costs are in 2006 prices. All results covering the three questions in the Introduction are given in Table 6 as external costs for the whole of Europe. For international ship traffic and for all emissions from the whole of Europe, simulations for four different years $(2000,2007,2011$, and 2020) were carried out in order to examine the evolution of these costs over time. From the results in Table 6, including the total health cost externalities, combined with the results for health impacts in Tables 2-5, we can now answer the questions defined in the Introduction.

Answering question 1, emissions from international ship traffic (scenarios All/15) constitute a major problem in terms of its impacts on human health. According to Corbett and Fischbeck (1997), pollution from international ship traffic causes roughly 60000 mortalities each year worldwide. In our calculations with the EVA system, only the human health impacts in Europe were taken into account. The impacts on human health are given in Table 2. According to our results, the number of premature deaths due to ship emissions for Europe alone is 49500 for the year 2000 increasing to 53400 in the year 2020 (YOLL divided by the factor 10.6 given in the CAFE report; Watkiss et al., 2005). A similar study for the USA performed by the US-EPA estimates 21000 premature deaths in the US with a related external cost of 47-110 bn USD in the year 2020 (US-EPA, 2009), which would suggest that the result by Corbett and Fischbeck (1997) might be underestimated. We estimate that the total external costs

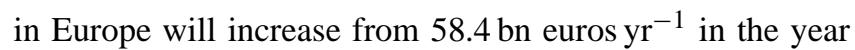
2000 to 64.1 bn euros $\mathrm{yr}^{-1}$ in the year 2020 . In the intervening years, smaller decreases are seen. The decrease for the years 2007 and 2011 is due to regulations in the sulfur content in the fuel used by the ships in the SECA, while the increase in the total external costs for the year 2020 is due to a projected increase in ship traffic worldwide.

If we examine the external costs from all international ship traffic (All/15) in relation to the other sources, then the ship traffic is estimated to be responsible for $7 \%$ of the total health effects in Europe due to air pollution in the year 2000, increasing to $12 \%$ in the year 2020 . The corresponding numbers for Denmark (not shown in the tables), which is surrounded by heavy ship traffic, are $18 \%$ in the year 2000 and $19 \%$ in the year 2020. Even though the total health-related external costs are decreasing from 805 million euros/year to 484 million euros/year in Denmark, the contribution from international ship traffic remains unchanged.

Answering question 2, the Baltic Sea and the North Sea are included in the SECAs, and it is therefore particularly interesting from a northern European point of view to investigate the impacts from regulating these areas. Furthermore, the ship traffic in these areas is relatively large compared to other regions of the world. According to our results, the total health-related external cost from international ship traffic in the SECA is 22.0 bn euros $\mathrm{yr}^{-1}$ for the year 2000 , decreasing to 14.1 bn euros $\mathrm{yr}^{-1}$ for the year 2020 . The impacts on health related to this emission sector are given in Table 3.

For Denmark, we estimate that the external costs due to international ship traffic in the Baltic Sea and the North Sea are 627 million euros $\mathrm{yr}^{-1}$ for the year 2000, decreasing to 357 million euros $\mathrm{yr}^{-1}$ for the year 2020 - a decrease of $43 \%$. From this we can conclude that the regulatory efforts of reducing sulfur emissions in the SECA are expected to reduce health-related external costs significantly. This indicates that a similar regulation of the international ship traffic in the whole world would have a significant positive effect on human health.

However, the impacts from ship emissions in the SECA remain significant. The reason for this is that the $\mathrm{NO}_{\mathrm{x}}$ emissions from international ship traffic are not regulated in this scenario, and $\mathrm{NO}_{\mathrm{x}}$ is a precursor for nitrate particles $\left(\mathrm{NO}_{3}^{-}\right)$. In fact, if we calculate the contribution to external costs in Denmark from international ship traffic in the Baltic Sea and the North Sea, in relation to the external costs from the total pollution levels (by dividing the results from BaS-NoS/15 with All/all for the respective years), it remains nearly constant at $14 \%$ over the years from the year 2000 to the year 2020 due to the similar decrease in the total air pollution levels from other sources.

Answering question 3, the total health-related external costs in Europe due to the total air pollution levels from all emission sources in the Northern Hemisphere are calcu-

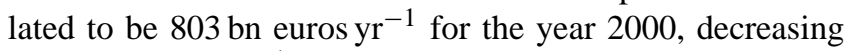
to $537 \mathrm{bn}^{2}$ euros $\mathrm{yr}^{-1}$ in the year 2020 (scenarios All/all). The decrease in the costs is due to the general emission reductions in Europe following the anticipated implementation of the NEC-II, and also due to the regulation of international ship traffic by introducing the SECAs. For Denmark, the estimated external costs are $4.54 \mathrm{bn}^{-} \mathrm{uros}_{\mathrm{yr}}{ }^{-1}$ for the year 2000 , decreasing to 2.53 bn euros $\mathrm{yr}^{-1}$ in the year 2020 . The total impacts on human health from the past, present and future air pollution levels are given in Table 4. 
Table 5. The total external costs in million euros for the whole of Europe per chemical compound for all the different scenarios. Total $\mathrm{S}$ is the sum of the external cost of $\mathrm{SO}_{2}$ and $\mathrm{SO}_{4}^{2-}$. Total $\mathrm{N}$ is the sum of the external costs of $\mathrm{O}_{3}$ and $\mathrm{NO}_{3}^{-}$. The external costs from $\mathrm{NH}_{3}$ emissions are included in the impacts related to $\mathrm{S}$ and $\mathrm{N}$ through chemical reactions in the atmosphere.

\begin{tabular}{lccccc}
\hline $\begin{array}{l}\text { Region/ } \\
\text { SNAP }\end{array}$ & $\begin{array}{c}\text { Emission } \\
\text { year }\end{array}$ & $\begin{array}{c}\text { CO } \\
{[\text { MEuros }]}\end{array}$ & $\begin{array}{c}\text { Total S } \\
{[\text { MEuros }]}\end{array}$ & $\begin{array}{c}\text { Total N } \\
{[\text { MEuros }]}\end{array}$ & $\begin{array}{c}\text { PM }_{2.5} \\
{[\text { MEuros }]}\end{array}$ \\
\hline All/15 & 2000 & 0.775 & 27000 & 25200 & 6110 \\
All/15 & 2007 & 0.707 & 23400 & 28500 & 5000 \\
All/15 & 2011 & 0.688 & 21000 & 28700 & 4600 \\
All/15 & 2020 & 0.849 & 24300 & 35400 & 4460 \\
BaS-NoS/15 & 2000 & 0.038 & 11600 & 8170 & 2270 \\
BaS-NoS/15 & 2007 & 0.051 & 5970 & 10100 & 1050 \\
BaS-NoS/15 & 2011 & 0.051 & 3550 & 10400 & 725 \\
BaS-NoS/15 & 2020 & 0.022 & 360 & 13200 & 490 \\
All/all & 2000 & 139 & 320000 & 331000 & 151000 \\
All/all & 2007 & 123 & 247000 & 307000 & 128000 \\
All/all & 2011 & 122 & 243000 & 307000 & 128000 \\
All/all & 2020 & 125 & 160000 & 235000 & 142000 \\
\hline
\end{tabular}

Table 6. Total health-related externalities for Europe and Denmark for international ship traffic (All/15), for international ship traffic in the Baltic Sea and the North Sea (BaS-NoS/15), and for all emissions in the whole of Europe (All/all) for four different emission years. All costs are in 2006 prices. All external costs are given in billion (bn) euros.

\begin{tabular}{lccc}
\hline Region/SNAP & $\begin{array}{c}\text { Emission } \\
\text { year }\end{array}$ & $\begin{array}{c}\text { Sum Europe } \\
\text { [bn euros] }\end{array}$ & $\begin{array}{c}\text { Sum Denmark } \\
\text { [bn euros] }\end{array}$ \\
\hline All/15 international ship traffic & 2000 & 58.4 & 0.805 \\
& 2007 & 56.9 & 0.623 \\
& 2011 & 54.3 & 0.558 \\
& 2020 & 64.1 & 0.484 \\
\hline BaS-NoS/15 international ship traffic in & 2000 & 22.0 & 0.627 \\
Baltic Sea and North Sea & 2007 & 17.2 & 0.474 \\
& 2011 & 14.7 & 0.414 \\
& 2020 & 14.1 & 0.357 \\
\hline All/all Emissions from the whole model & 2000 & 803 & 4.54 \\
domain, all anthropogenic emission & 2007 & 682 & 3.80 \\
sectors and all natural sources & 2011 & 678 & 3.75 \\
& 2020 & 537 & 2.53 \\
\hline
\end{tabular}

\subsection{Comparison with results from Clean Air for Europe}

In this subsection, we compare results from the EVA model system with overall results from the last baseline report from Clean Air for Europe (CAFE) (Watkiss et al., 2005). The main goal of the CAFE programme, launched in 2001 by the EU Commission, was: "achieving levels of air quality that do not give rise to significant negative impacts on and risks to human health and the environment". The analysis by Watkiss et al. (2005) includes estimates of air pollution concentrations from the EMEP model (European Monitoring and Evaluation Programme) coupled with impact assessment from the RAINS model, including human health, environmental impacts, and external costs. The report includes an assessment of the impacts on human health and the environment from the total air pollution levels in the years 2000 and 2020 - these results are therefore a good basis for comparison with results in this work. Clearly, air pollution concentrations predicted for hypothetical scenarios cannot be validated against real measurement data. While it is possible to test the individual parts of the EVA system (e.g. comparing estimated concentrations from DEHM with observations, validating exposureresponse functions and economic valuations), it is difficult to validate the system as a whole, except by comparing EVA estimates with results of similar studies.

These comparisons constitute the closest we can come to an overall evaluation of the whole integrated EVA model system. If the results for health impacts and external costs are similar for the total air pollution levels, then we can have greater confidence in the results from the scenarios, yet we 
emphasize that the two results being compared are both subject to significant uncertainties and different assumptions. The same kind of comparison does not apply for the scenarios, since scenarios in the CAFE results are based on linear assumptions from predefined source-receptor relationships, while the EVA system takes into account the full non-linear atmospheric chemistry. Therefore, any difference in the scenario results could arise from the linear vs. non-linear approach. The linear assumptions of atmospheric chemistry do not apply for the total air pollution levels in the CAFE calculations, since these are based on pure model results from a chemistry transport model.

In the results presented in this paper, we have assessed the total impacts on human health (see Table 4) and the corresponding external costs (see Table 6) from the total air pollution levels, including all anthropogenic and natural sources for the Northern Hemisphere for four different years (2000, 2007, 2011, and 2020). The scenario is denoted All/all in the tables, meaning that all regions and all emissions for the whole model domain are included. These results are directly comparable with the results in Watkiss et al. (2005). In the following, a direct comparison is made for some of the key parameters in the study. We will denote the results provided in Watkiss et al. (2005) as "CAFE" and the results in this report as "EVA".

The YOLL (years of life lost) is a key parameter for the overall mortality. The comparable numbers in CAFE and EVA are as follows: in the CAFE study the result was: "Annual impacts across the EU 25 total an estimated 3.7 million years of life lost each year (based on the year 2000). This can also be expressed as 348000 estimated premature deaths". EVA estimates 7.2 million YOLL and 680000 estimated premature deaths, based on the year 2000 in the European model domain. The estimate from the EVA system is twice the estimate from the CAFE study. However, the CAFE results apply for the EU-25 countries and the EVA results are valid for the whole of Europe, including approximately twice as many people (approx. 450 million people in EU-25 and a total of 850 million people in the European model domain), thus partially accounting for the difference between the two estimates.

For the impacts of hospital admissions, the two studies provide the following results: for CAFE, "The morbidity effects of PM is estimated to around 100000 cases of respiratory or cardiac hospital admissions". For EVA, the estimates are as follows: 38000 respiratory hospital admissions +81000 cerebrovascular hospital admissions giving a total of around 119000 cases for the year 2000 for the European model domain. For the impacts of restricted activity days, CAFE estimates, "several hundred million restricted activity days each year". EVA estimates 647 million restricted activity days (European model domain).

For the total external costs, the comparable figures from the two studies are as follows: for CAFE, core estimates of annual health impacts due to air pollution in 2000 and in
2020 in EU-25 are 790 bn euros and 609 bn euros, respectively (using the "value of a statistical life" mean). For EVA, total external cost in 2000 (European domain) is 803 bn euros and 537 bn euros for the year 2020 using the YOLL approach. The total external costs are very similar for the two studies for the two years. However since the European domain in DEHM covers nearly twice as many people, the EVA results for the EU-25 countries are therefore lower than the CAFE results. The difference in the total external costs also arises from the fact that the valuation in CAFE is based on value of a statistical life (VSL) whereas the EVA results are based on value of a life year (VOLY). In CAFE, VSL results were higher than those using VOLYs and this can also explain the higher total external costs for Europe compared to the results obtained by EVA.

In the year 2000, the gross domestic product (GDP) of the EU-25 countries was 8947 bn euros (Watkiss et al., 2005), so the total external costs related to impacts on human health constitute a significant fraction of the GDP. The total external cost in Denmark according to EVA is 4.54 bn euros (34 bn DKK) for the year 2000, which corresponds to approximately $2 \%$ of the Danish GDP. The total external cost due to the total air pollution levels for Denmark is expected to decrease to 2.53 bn euros in the year 2020 (see Table 3). The corresponding figure for the year 2000 in the CAFE study is 7.3 bn euros. Compared to our results of 4.54 bn euros for the same year, we can conclude that our results are conservative.

Another parameter of interest is the number of premature deaths in Denmark. Using the EVA system, we calculate 42700 YOLL for the year 2000 for Denmark. If we convert this to premature deaths (dividing by a factor of 10.6, as suggested by the CAFE report), we get approximately 4000 premature deaths per year in Denmark, which is very similar to other Danish estimates (e.g. Raaschou-Nielsen et al., 2002). For the years 2007 and 2020, the corresponding figures are 3400 and 2200 for Denmark, showing an expected decrease in the year 2020 to nearly half the number in the year 2000 .

In general, we can conclude that the comparable figures presented here from the CAFE study and the EVA results are quite similar, especially if we take into account that we compare the EU-25 countries (CAFE) with the whole European model domain 2 (EVA), which also includes parts of Russia, Ukraine, Belarus, Turkey, etc. We conclude that the results provided by the EVA model system are in satisfactory agreement with results previously published in the literature.

However, we emphasize that comparing the overall results for the general air pollution levels does not mean that the results for the different scenarios are similar. This relates to key differences between the EVA and RAINS systems: when handling scenarios, RAINS applies linearized approximations to the source-receptor relationships. EVA simulates the actual scenarios every time taking into account the non-linear effects of atmospheric chemistry (see e.g. Bastrup-Birk et al., 1997) and using our tagging method, reducing the signal-tonoise ratio in the $\delta$-functions. A study of the contributions 
from the individual SNAP emission categories in Europe is given in Brandt et al. (2013).

\section{Overall conclusions}

In this paper we have presented a new integrated model system, EVA, based on the impact-pathway approach and customized for European conditions. The system is capable of calculating the health-related external costs from specific emission sources and sectors. The system represents an attempt to apply state-of-the-art science, models, data, and methodologies in every link of the impact-pathway chain. Furthermore, we have implemented a tagging method, where the problem with signal-to-noise ratio has been reduced in the calculation of the source contributions (the $\delta$-functions).

The EVA system has been run for different scenarios, assessing the human health impacts and associated external costs from international ship traffic as well as the total concentration levels for four different years $(2000,2007,2011$, and 2020). The results have been contrasted with comparable figures from the Clean Air For Europe (CAFE) project, and we have concluded that the results from the two systems are in satisfactory agreement.

International ship traffic constitutes a major problem in relation to impacts on human health. We estimate that the total external costs in Europe will increase from 58.4 bn euros $\mathrm{yr}^{-1}$ in the year 2000 to 64.1 bn euros $\mathrm{yr}^{-1}$ in the year 2020 due to an expected general increase in the ship traffic worldwide. If we examine the relative external costs from all international ship traffic, it is responsible for an estimated $7 \%$ of the total health effects in Europe due to air pollution in the year 2000, increasing to $12 \%$ in the year 2020 .

According to our results, the total health-related external costs from international ship traffic in the Baltic Sea and the North Sea are 22.0 bn euros $\mathrm{yr}^{-1}$ for the year 2000, decreasing to 14.1 bn euros $\mathrm{yr}^{-1}$ for the year 2020 - a decrease of $36 \%$. For Denmark alone, the impacts from international ship traffic in the Baltic Sea and the North Sea result in external costs of an estimated 627 million euros $\mathrm{yr}^{-1}$ for the year 2000 , falling to an estimated 357 million euros $\mathrm{yr}^{-1}$ for the year 2020 - a decrease of $43 \%$. From this we conclude that the regulatory efforts of reducing sulfur emissions in the SECA are expected to significantly reduce the health-related external costs of international shipping. However, the problem of impacts from ship emissions in this area remains significant due to $\mathrm{NO}_{\mathrm{x}}$ emissions, which lead to the formation of nitrate particles $\left(\mathrm{NO}_{3}^{-}\right)$. In fact, if we examine the relative external costs in Denmark from international ship traffic in the Baltic Sea and the North Sea, with respect to the total external costs from all emission sources, it is expected to remain nearly constant at roughly $14 \%$ over the years from the year 2000 to the year 2020 due to the similar decrease in the total air pollution levels. From this we can also conclude that the relative contribution from the international ship traffic is of comparable size to the contributions from road traffic or the use of domestic wood stoves in Denmark (see Brandt et al., 2013).

For Denmark, the external costs related to all international ship traffic are expected to decrease from 805 million euros $\mathrm{yr}^{-1}$ in the year 2000 to 484 million euros $\mathrm{yr}^{-1}$ in the year 2020. This is a direct result of the introduction of the SECA, where the sulfur content in the heavy fuel is reduced from $2.7 \%$ in the year 2000 to $0.1 \%$ in the year 2015 . The relative health-related external costs in Denmark from international ship traffic are estimated to be $18 \%$ in the year 2000 and $19 \%$ in the year 2020, even though the total external costs are decreasing due to a general decrease in air pollution levels. Introducing regulatory instruments for all international ship traffic similar to the ones introduced with the SECA would have a significant positive impact on human health in Europe.

The total health-related external costs in Europe due to the total air pollution levels from all emission sources in the Northern Hemisphere are calculated to be 803 bn euros $\mathrm{yr}^{-1}$ for the year 2000 decreasing to $537 \mathrm{bn}$ euros $\mathrm{yr}^{-1}$ in the year 2020. The decrease is due to the general emission reductions in Europe provided that the NEC-II is implemented as a directive and given the regulation of international ship traffic by introducing SECA in the North Sea and Baltic Sea. The results from the EVA system have been proven consistent with the results from the CAFE study, which have been used to support decision-making in the EU Commission. For Denmark the external costs are estimated to be 4.54 bn euros $\mathrm{yr}^{-1}$ for the year 2000, decreasing to 2.53 bn euros $\mathrm{yr}^{-1}$ in the year 2020.

The results in this study show that air pollution still constitutes a serious problem for human health and that the related external costs are considerable. In this work, we defined three overall questions that illustrate the capability of the EVA system to give useful input for the planning and prioritization of regulation policies and instruments.

Acknowledgements. The present study is a part of the research of the Centre for Energy, Environment and Health (CEEH), financed by The Danish Strategic Research Program on Sustainable Energy under contract no. 2104-06-0027. Home page is www.ceeh.dk.

Edited by: S. Galmarini

\section{References}

Alcamo, J., Shaw, R., and Hordijk, L. (eds.): The RAINS Model of Acidification. Science and Strategies in Europe, Kluwer Academic Publishers, Dordrecht, the Netherlands, 402 pp., 1990.

Amann, M., Bertok, I., Cabala, R., Cofala, J., Heyes, C., Gyarfas, F., Klimont, Z., Schöpp, W., and Wagner, F.: A final set of scenarios for the Clean Air For Europe (CAFE) programme, June 2005, International Institute for Applied Systems Analysis (IIASA) CAFE Scenario Analysis Report Nr. 6. http://www.iiasa.ac.at/ 
rains/CAFE_files/CAFE-D3.pdf (last access: 25 February 2013), 2005.

Andersen, M. S., Frohn, L. M., Nielsen, J. S., Nielsen, M., Jensen, J. B., Jensen, S. S., Christensen, J., and Brandt, J.: EVA - a nonlinear, Eulerian approach for assessment of health-cost externalities of air pollution, Biennial Conference of the International Society for Ecological Economics, New Delhi, December 2006.

Andersen, M. S., Frohn, L. M., Brandt, J., and Jensen, S. S.: External effects from power production and the treatment of wind energy (and other renewables) in the Danish energy taxation system, in: Critical Issues in Environmental Taxation: International and Comparative Perspectives Volume IV edited by: Deketelaere, K., Milne, J. E., Kreiser, L. A., Ashiabor, H., Oxford University Press, NC, USA, 319-336, 2007.

Andersen, M. S., Frohn, L. M., Nielsen, J. S., Nielsen, M., Jensen, S. S., Christensen, J. H., and Brandt, J.: A Non-linear Eulerian Approach for Assessment of Health-cost Externalities of Air Pollution. Proceedings of the European Association of Environmental and Resource Economists 16th Annual Conference, Gothenburg, Sverige, 25-28 June 2008, 23 pp., 2008.

Bastrup-Birk, A., Brandt, J., Zlatev, Z., and Uria, I.: Studying cumulative ozone exposures in Europe during a 7-year period, J. Geophys. Res., 102, 23917-23935, 1997.

Brandt, J., Christensen, J. H., Frohn, L. M., Palmgren, F., Berkowicz, R., and Zlatev, Z.: Operational air pollution forecasts from European to local scale. Atmos. Environ., 35, Supp. No. 1, S91S98, 2001a.

Brandt, J., Christensen, J. H., Frohn, L. M., and Berkovicz, R.: Operational air pollution forecast from regional scale to urban street scale. Part 1: system description, Phys. Chem. Earth B, 26, 781786, $2001 \mathrm{~b}$.

Brandt, J., Christensen, J. H., and Frohn, L. M.: Operational air pollution forecast from regional scale to urban street scale. Part 2: performance evaluation, Phys. Chem. Earth B, 26, 825-830, 2001c.

Brandt, J., Christensen, J. H., Frohn, L. M., and Berkowicz, R.: Air pollution forecasting from regional to urban street scale - implementation and validation for two cities in Denmark, Phys. Chem. Earth, 28, 335-344, 2003.

Brandt, J., Christensen, J. H., Frohn, L. M., Geels, C., Hansen, K. M., Hedegaard, G. B., Hvidberg, M., and Skjøth, C. A.: THOR - an operational and integrated model system for air pollution forecasting and management from regional to local scale. Proceedings of the 2nd ACCENT Symposium, Urbino (Italy), 23-27 July, 2007.

Brandt, J., Silver, J. D., Christensen, J. H., Andersen, M. S., Geels, C., Gross, A., Hansen, A. B., Hansen, K. M., Hedegaard, G. B., and Skjøth, C. A.: Assessment of Health-Cost Externalities of Air Pollution at the National Level using the EVA Model System. Proceedings from the International Conference on Energy, Environment and Health - Optimisation of Future Energy Systems, 31 May-2 June 2010, Carlsberg Academy, Valby, Denmark, pp. 5. http://www.ceeh.dk/CEEH_Reports/Report_9/ CEEH_Scientific_report_9.pdf (last access: 25 February 2013), 2010

Brandt, J., Silver, J. D., Frohn, L. M., Geels, C., Gross, A., Hansen, A. B., Hansen, K. M., Hedegaard, G. B., Skjøth, C. A., Villadsen, H., Zare, A., and Christensen, J. H.: An integrated model study for Europe and North America using the
Danish Eulerian Hemispheric Model with focus on intercontinental transport, Atmos. Environ., 53, June 2012, 156-176, doi:10.1016/j.atmosenv.2012.01.011, 2012.

Brandt, J., Silver, J. D., Christensen, J. H., Andersen, M. S., Bønløkke, J. H., Sigsgaard, T., Geels, C., Gross, A., Hansen, A. B., Hansen, K. M., Hedegaard, G. B., Kaas, E., and Frohn, L. M.: Contribution from the ten major emission sectors in Europe and Denmark to the health-cost externalities of air pollution using the EVA model system - an integrated modelling approach, Atmos. Chem. Phys., 13, 7725-7746, doi:10.5194/acp-13-77252013, 2013.

Christensen, J. H.: The Danish Eulerian Hemispheric Model - a three-dimensional air pollution model used for the Arctic, Atmos. Environ., 31, 4169-4191, 1997.

Christensen, J. H., Brandt, J., Frohn, L. M., and Skov, H.: Modelling of Mercury in the Arctic with the Danish Eulerian Hemispheric Model, Atmos. Chem. Phys., 4, 2251-2257, doi:10.5194/acp-42251-2004, 2004.

Corbett J. J. and Fischbeck, P. S.: Emissions from ships, Science, 278, 823-824, 1997.

ExternE: National Implementation, Germany, Contract JOS3CT95-0010, Contract JOU2-CT-0264. Final Report prepared by IER, November 1997, IER, University of Stuttgart, Hessbruehlstr. 49a, 70565 Stuttgart, Germany, 1997.

ExternE DGXII (JOULE Programme), Externalities of Energy, External project, Report Number 7, Methodology: edited by: Holland, M. R. and Foster, D., www.externe.info (last access: 25 February 2013), 1998.

ExternE: ExternE - Externalities of Energy: Vol. 7, Methodology, European Commission, Brussels, 1999.

ExternE: Externalities of Energy Methodology 2005 update, European Commission, Directorate-General for Research Sustainable Energy Systems, Brussels, 2005.

Friedrich, R. and Bickel, P.: Environmental External Costs of Transport, Springer, München, Germany, 326 pp., 2001.

Frohn, L. M., Christensen, J. H., Brandt, J., and Hertel, O.: Development of a high resolution nested air pollution model for studying air pollution in Denmark, Phys. Chem. Earth, 26, 769-774, 2001.

Frohn, L. M., Christensen, J. H., and Brandt, J.: Development of a high resolution nested air pollution model - the numerical approach, J. Comp. Phys., 179, 68-94, 2002.

Frohn, L. M., Brandt, J., Hertel, O., Christensen, J. H., Geels, C., Andersen, M. S., Nielsen, J. S., Frydendall, J., Hvidberg, M., Jensen, S. S., Petersen, J., and Madsen, P. V.: Assessment of air pollution related damages on human health - and the subsequent costs, Proceedings from the 3rd GLOREAM/ EURASAP Workshop, Modern developments in modelling and chemical data analysis, the Netherlands, September 2005, 8 pp., 2006.

Frohn, L. M., Andersen, M. S., Geels, C., Brandt, J., Christensen, J. H., Hansen, K. M., Nielsen, J. S., Hertel, O., Skjøth, C. A., and Madsen, P. V.: "EVA - An integrated model system for assessing external costs related to air pollution emissions. A contribution to ACCENT T\&TP”, Proceedings from the $2^{\text {nd }}$ ACCENT Symposium, 10 pp., www.accent-network.org (last access: 25 February 2013), 2007.

Hänninen, O., Knol, A. (eds.), Jantunen, M., Kollanus, V., Leino, O., Happonen, E., Lim, T.-A., Conrad, A., Rappolder, M., Carrer, P., Fanetti, A.-C., Kim, R., Prüss-Üstün, A., Buekers, J., Torfs, R., Iavarone, I., Comba, P., Classen, T., Hornberg, C., and 
Mekel, O.: European perspectives on Environmental Burden of Disease: Estimates for nine stressors in six countries. THL Reports $1 / 2011$, Helsinki, Finland, 86 pp. and 2 appendixes, ISBN 978-952-245-413-3, http://en.opasnet.org/w/Ebode (last access: 25 February 2013), 2011.

Jensen, G. and Leetz, A. (Eds.): Acting now for better health: A $30 \%$ target for EU climate policy, 40 pp., http://www.env-health. org/IMG/pdf/HEAL_30_co-benefits_report_-_FULL.pdf (last access: 25 February 2013), 2010.

Klaassen, G., Amann, M., Berglund, C., Cofala, J., HöglundIsaksson, L., Heyes, C., Mechler, R., Tohka, A., Schöpp, W., and Winiwarter, W.: The extension of the RAINS model to greenhouse gases. Technical Report IR-04-015, International Institute for Applied Systems Analysis, Laxenburg, Austria, 2004.

Pfister, G. G., Emmons, L. K., Hess, P. G., Lamarque, J.-F., Orlando, J. J., Walters, S., Guenther, A., Palmer, P. I., and Lawrence, P. J.: Contribution of isoprene to chemical budgets: A model tracer study with the NCAR CTM MOZART-4, J. Geophys. Res., 113, D05308, doi:10.1029/2007JD008948, 2008.
Raaschou-Nielsen, O., Palmgren, F., Jensen, S. S., Wåhlin, P., Berkowicz, R., Hertel, O., Vrang, M.-L., and Loft, S. H.: Helbredseffekter af partikulær luftforurening i Danmark - et fors $\varnothing \mathrm{g}$ på kvantificering, Ugeskrift for Læger, 164, 3959, 2002.

Sudo, K. and Akimoto, H.: Global source attribution of trophospheric ozone: long-range transport from various source regions, J. Geophys. Res., 112, D12302, doi:10.1029/2006JD007992, 2007.

US-EPA: Proposal of Emission Control Area Designation for Geographic Control of Emissions from Ships. United States Environmental Protection Agency, Office of Transportation and Air Quality EPA-420-F-09-015, 8 pp., December 2009, Washington, USA, 2009.

Watkiss, P., Pye, S. and Holland, M.: CAFE CBA: Baseline Analysis 2000 to 2020. Service Contract for Carrying out Cost-Benefit Analysis of Air Quality Related Issues, in particular in the clean Air for Europe (CAFE) Programme, April 2005, http://www. cafe-cba.org/assets/baseline_analysis_2000-2020_05-05.pdf (last access: 25 February 2013), 2005. 